\title{
Socio-Economic Development and Occupational Health and Safety in Developing Countries
}

\author{
Alpaslan Türkkan* \\ Department of Public Health, Uludag University, Turkey
}

"Corresponding author: Alpaslan Türkkan, Department of Public Health, Uludag University, Turkey. Tel: +90 2242954281; Fax: +902242954261; Email: alpaslanturkkan@gmail.com

Citation: Türkkan A (2017) Socio-Economic Development and Occupational Health And Safety In Developing Countries. J Community Med Public Health: CMPH-104. DOI: 10.29011/CMPH-104/100004

Received Date: 14 July, 2017; Accepted Date: 26 July, 2017; Published Date: 2 August, 2017

\begin{abstract}
Background: Although there have been a substantial number of studies conducted on occupational health and safety, less attention has been paid to importance of the impact of Socio-Economic Development (SED) status on occupational injury incidence rates, mortality and fatality.

Objectives: To analyze the relationship between the SED status and occupational health and the safety status with respect to this level of variance.

Methods: the socio-economic development level of regions, provinces and districts data were obtained from two researches. Health and safety data were obtained from the Annual Statistics Books of the Social Insurance Institution and the Social Security Institution. The occupational injury incidence rate and occupational mortality and fatality rates were used as indicators of occupational health and safety.

Findings: Occupational injury incidence rates and mortality have decreased, with occupational injury incidence rates decreasing by half. Occupational injury incidence rates are clearly incompatible with the degree of socio-development. Injury incidence rates are highest in the most developed cities, and these rates are 5 times greater than those in the least developed cities. Occupational fatality is clearly compatible with the degree of development.

Conclusions: While evaluating the occupational health and safety in developing countries, occupational fatality as opposed to occupational injury incidence rate should be taken into consideration.
\end{abstract}

Keywords: Fatality; Mortality; Occupational Injury; SocioEconomic Development; Turkey

\section{Introduction}

Recent studies have demonstrated that occupational health and safety are closely related to the economic development and the economic cycle of a country [1-3]. The relationship between the rate of occupational injury and the Gross Domestic Product (GDP), which is an accepted indicator of economic development, has been taken into consideration in many studies. A higher GDP is significantly related to a lower rate of occupational injury $[1,2,4]$. There is a wide variation in occupational injury rates by country, and these rates are often greater than for other injuries [5]. Gener- ally speaking, occupational safety situations in developed countries are better than in developing countries.

Although there have been a substantial number of studies conducted on occupational health and safety, less attention has been paid to importance of the impact of Socio-Economic Development (SED) status on occupational injury incidence rates, mortality and fatality. To the best of our knowledge, no study has evaluated the impact of SED status and these variables with a particular index, or with the change in this status and the occupational health and safety situations. The aim of this study was to analyze the relationship between the SED status and occupational health and the safety status with respect to this level of variance. 


\section{Methods}

\section{Socio-economic development data}

The State Planning Organization (DPT) occasionally conducts studies to determine the socio-economic development level of regions, provinces and districts in Turkey. The last study was carried out in 2003 [6]. Despite the announcement that similar studies would be carried out periodically every 5 years, the next study was not published until 2012. However, these two studies cannot be compared with each other due to their use of different techniques. This lack of information can be eliminated by comparing the Y1ldız, et al. study with the 2003 DPT study [7]. Fifty-eight variables were used in the DPT study, and 41 variables were used in the Yıldız, et al. study. Both studies used social (Demographic, Employment, Education, Health, Infrastructure, Welfare) and economic variables (Production, Construction, Agriculture, And Financial Status). Principal components analysis can also be used to determine the socio-economic development of the cities. In 2003, with the help of the DPT5, different development degrees were determined in Turkey. Accordingly, the 5 most developed cities are designated as Degree 1. Following these cities, 20 are designated as Degree 2 cities, 21 are designated as Degree 3 cities, 21 are designated as Degree 4 cities, and 19 are designated as Degree 5. The degree for 16 cities has yet to be determined. We also developed a 5-degree development status for the Yildiz, et al. study. In addition; the development between 2003 and 2011 has been taken into consideration. Prior to the first study, the cities that ranked higher on the development scale were marked as "progressive", the ones that ranked lower on the scale were deemed to be "Regressive", and the ones that were at the same place were marked as "Unchanged".

\section{Occupational health and safety data}

Health and safety data were obtained from the Annual Statistics Books of the Social Insurance Institution (SII) and the Social Security Institution (SSI) $[8,9]$. Workers in informal sectors, agriculture, white-collar workers in government offices, seafarers and self-employed workers are not covered in these surveillance systems. The data from the DPT (2003) study has been compared with the SII (year 2000) study and the data from Yildız, et al. (2011) along with the 2009 SSI statistics annual report on occupational health and safety status. This year's (2000 and 2009) were chosen because the DPT and Yildiz, et al. studies were conducted in this year and because the data were collected throughout the year. The occupational injury incidence rate and occupational mortality and fatality rates were used as indicators of occupational health and safety.

\section{They were calculated as follows:}

Occupational injury incidence rate $=$ (number of occupational injuries/total number of workers) $\times 1,000$
Occupational mortality $=$ (number of deaths/total number of workers) $\times 100,000$

Occupational fatality $=$ (number of deaths/number of occupational injuries) $\times 1,000$

Occupational health and safety variables were related to the city's socio-economic development on a scale of 1-5, with1 being the highest and 5 being the lowest for the number of compulsorily insured, the number of occupational injuries and the number of deaths, whereas 1 was the lowest and 5 was the highest for occupational injury incidence rate, mortality and fatality. We calculated the index value based on the year 2000. The index has been compared to the year 2009, and both the development degree and the change in the development degree were considered.

\section{Results}

The compulsory insurance rate increased by $72 \%$ between the years of 2000 and 2009 in Turkey. Occupational injury incidence rates and mortality have decreased, with occupational injury incidence rates decreasing by half. Occupational fatality is the only measure that increased directly with the number of insured (Table 1).

\begin{tabular}{|c|c|c|c|}
\hline & 2000 & 2009 & Difference (\%) \\
\hline $\begin{array}{c}\text { Number of compulsorily } \\
\text { insured employees }\end{array}$ & $5,254,125$ & $9,030,202$ & +71.9 \\
\hline $\begin{array}{c}\text { Number of work-related } \\
\text { injuries }\end{array}$ & 75,650 & 64,742 & -14.4 \\
\hline Number of deaths & 1,291 & 1,171 & -9.3 \\
\hline $\begin{array}{c}\text { Occupational injury } \\
\text { incidence rate }\end{array}$ & 14.4 & 7.2 & -50.0 \\
\hline $\begin{array}{c}\text { Occupational mortality } \\
\text { rate }{ }^{\mathrm{b}}\end{array}$ & 22.3 & 13.0 & -41.7 \\
\hline $\begin{array}{c}\text { Occupational fatality } \\
\text { rate }\end{array}$ & 15.5 & 18.1 & +16.8 \\
\hline${ }^{\mathrm{a}}$ Occupational injury incidence rate is defined as the number of inju- \\
ries per 1000 workers. \\
\hline${ }^{\mathrm{b}}$ Mortality rate is defined as the number of deaths per 100,000 work- \\
ers.
\end{tabular}

Table 1: Occupational health and safety and change between 2000 and 2009.

The cities that are the most developed are the ones with the most workers, the most injuries and the most death. These measures decrease with a city's decreasing level of development. Occupational injury incidence rates are clearly incompatible with the degree of socio-development. Injury incidence rates are highest in the most developed cities, and these rates are 5 times greater than those in the least developed cities (Table 2). 
Citation: Türkkan A (2017) Socio-Economic Development and Occupational Health And Safety In Developing Countries. J Community Med Public Health: CMPH-104.

\begin{tabular}{|c|c|c|c|c|c|c|c|c|c|c|c|c|}
\hline & \multicolumn{2}{|c|}{$\begin{array}{c}\text { Compulsory insured } \\
\text { employees \% }\end{array}$} & \multicolumn{2}{|c|}{$\begin{array}{c}\text { Work-related inju- } \\
\text { ries } \%\end{array}$} & \multicolumn{2}{|c|}{ Death \% } & \multicolumn{2}{|c|}{$\begin{array}{l}\text { Occupational injury } \\
\text { incidence rate }^{\mathrm{a}}\end{array}$} & \multicolumn{2}{|c|}{$\begin{array}{l}\text { Occupational mor- } \\
\text { tality rate }\end{array}$} & \multicolumn{2}{|c|}{$\begin{array}{c}\text { Occupational fatal- } \\
\text { ity rate }\end{array}$} \\
\hline & 2000 & 2009 & 2000 & 2009 & 2000 & 2009 & 2000 & 2009 & 2000 & 2009 & 2000 & 2009 \\
\hline Degree 1 & $54.9(1)$ & $53.8(1)$ & $43.6(1)$ & $42.5(1)$ & $39.6(1)$ & $42.5(1)$ & $11.4(3)$ & $5.7(3)$ & $14.7(1)$ & $10.3(1)$ & $12.9(2)$ & $18.1(3)$ \\
\hline Degree 2 & $26.4(2)$ & $23.0(2)$ & 42.7 (2) & $36.5(2)$ & 33.9 (2) & $28.1(2)$ & $23.3(5)$ & $11.4(5)$ & $26.2(3)$ & $\begin{array}{l}15.8 \\
(3-4)\end{array}$ & $11.2(1)$ & $13.9(1)$ \\
\hline Degree 3 & $10.9(3)$ & $13.0(3)$ & $9.3(3)$ & $17.3(3)$ & $15.4(3)$ & $15.8(3)$ & $12.3(4)$ & $9.6(4)$ & $28.8(4)$ & $\begin{array}{l}15.8 \\
(3-4)\end{array}$ & $\begin{array}{l}23.4 \\
(3-4)\end{array}$ & $16.5(2)$ \\
\hline Degree 4 & $5.8(4)$ & $6.7(4)$ & $4.0(4)$ & $3.1(4)$ & $6.6(4)$ & $9.5(4)$ & $10.0(2)$ & $3.3(2)$ & $23.3(2)$ & $18.4(5)$ & $\begin{array}{l}23.4 \\
(3-4) \\
\end{array}$ & $55.1(4)$ \\
\hline Degree 5 & $2.0(5)$ & $3.5(5)$ & $0.4(5)$ & $0.5(5)$ & $4.4(5)$ & $4.1(5)$ & $2.6(1)$ & $1.1(1)$ & $44.7(5)$ & $15.0(2)$ & $172.2(5)$ & $139.5(5)$ \\
\hline Turkey & 100.0 & 100.0 & 100.0 & 100.0 & 100.0 & 100.0 & 14.4 & 7.2 & 22.3 & 13.0 & 15.5 & 18.1 \\
\hline \multicolumn{13}{|c|}{${ }^{\mathrm{a}}$ Occupational injury incidence rate is defined as the number of injuries per 1000 workers. } \\
\hline \multicolumn{13}{|c|}{${ }^{\mathrm{b}}$ Mortality rate is defined as the number of deaths per 100,000 workers. } \\
\hline \multicolumn{13}{|c|}{${ }^{\mathrm{c}}$ Fatality rate is defined as the number of deaths per 1000 injuries. } \\
\hline
\end{tabular}

Table 2: Occupational health and safety indicators and degree of SED between 2000 and 2009 (throughout the years)*.

Mortality is also compatible with the year of 2000. Occupational fatality is clearly compatible with the degree of development. Fatality rates in less developed cities are 13 times greater than in more developed cities in 2000, whereas this ratio decreases to 8 in the year 2009. Between the years of 2000 and 2009 in all levels of development, developing, unchanged and regressing cities experienced a decreasing rate of occupational injuries and occupational mortality. In the order of development, regressing cities had a lower rate of occupational injuries and mortality *Year 2000 is the index year. (Table 3 )

\begin{tabular}{|c|c|c|c|c|c|c|}
\hline & \multicolumn{2}{|c|}{ Occupational injury incidence rate } & \multicolumn{2}{|c|}{ Occupational mortality rate } & \multicolumn{2}{|c|}{ Occupational fatality rate } \\
\hline & 2000 & 2009 & 2000 & 2009 & 2000 & 2009 \\
\hline Degree 1 & 100.0 & 50.0 & 100.0 & 70.1 & 100.0 & 140.3 \\
\hline Degree 2 & 100.0 & 48.9 & 100.0 & 60.3 & 100.0 & 124.1 \\
\hline Degree 3 & 100.0 & 78.0 & 100.0 & 54.9 & 100.0 & 70.5 \\
\hline Degree 4 & 100.0 & 33.0 & 100.0 & 79.0 & 100.0 & 235.5 \\
\hline Degree 5 & 100.0 & 42.3 & 100.0 & 33.6 & 100.0 & 81.0 \\
\hline Progressive & 100.0 & 57.3 & 100.0 & 61.7 & 100.0 & 107.1 \\
\hline Unchanged & 100.0 & 50.8 & 100.0 & 65.6 & 100.0 & 129.5 \\
\hline Regressive & 100.0 & 41.8 & 100.0 & 60.7 & 100.0 & 144.5 \\
\hline Turkey & 100.0 & 50.0 & 100.0 & 58.3 & 100.0 & 116.8 \\
\hline
\end{tabular}

Table 3: The percentage change in injury incidence rates, mortality and fatality and SED between 2000-2009*. 
Developing cities had the lowest rate of progress in the occupational injury rate. These rates are followed by the cities whose development was unchanged. Occupational fatality decreased only among cities of Degree 3 and Degree 5. Developing, regressing and unchanged cities had an increasing occupational fatality rate, but the average increase in progressive cities was below the national average increase. Fatality was most increased in regressing cities.

\section{Discussion}

In the present paper, the socio-economic development and the change in development in Turkish cities between the years 2000 and 2009 has been studied with respect to occupational health and safety. This study is the first to include the evaluation of socio-economic development, which is determined with respect to many variables regarding the injury incidence rate, mortality and fatality. Our study shows that the occupational injury incidence rate, which is used frequently to determine occupational health and safety, is not an accurate method for determining socio-economic development in Turkish cities. Socio-economic development and changes in development are not reflected in the occupational injury incidence rate. Occupational fatality is the most compatible variable between socio-economic development and the change in development.

The statistical data and analysis on occupational health and safety are very important tools for further development of prevention policies [10]. Quality data are fundamental for understanding injury epidemiology and for designing interventions to decrease incidence, mortality and morbidity. Occupational data are published annually in many countries, but reliable data are available only in a limited number of countries [11]. Records kept in Turkey on injury incidence rates are insufficient [12]. In developing countries, fatal occupational injuries are reported more accurately than nonfatal injuries. It is likely that inadequate attention has been paid to minor non-fatal accidents in Turkey [13]. Inadequate records kept in Turkey are predicted to decrease the occupational injury incidence rate. The survey carried out by SII and SSI on the number of compulsorily insured workers and the data it contains on the number of workers who are injured or deceased does not cover all employees in Turkey.

\section{Conclusion}

These results can be used as a guide for national policy and decision-making. Looking at the relationship between socio-eco- nomic development and injury rate, and the relationship between mortality and fatality, will help to evaluate the record-keeping system as well as to determine the actual problem and where solutions should be focused. Developing countries have varying criteria, and records are often lost, inaccurate or incomplete. Thus, occupational injury incidence rates may be inaccurate due to the lack of collected data. However, the fatality rate will be a more accurate prediction once the recorded injury and fatality rates have been taken into consideration.

\section{References}

1. SongLi, He Xueqiu, Li Chengwu (2011) Longitudinal relationship between economic development and occupational accidents in China. Accid. Anal Prev 43: 82-86.

2. Barth A, Winker R, Ponocny-Seliger E (2007) Economic growth and incidence of occupational injuries in Austria. The Middle European Journal of Medicine 119: 158-163.

3. Cubbin C, LeClere F, Smith GS (2000) Socioeconomic Status and the Occurence of Fatal and Nonfatallnjury in the United States. Am J Public Health 90: 70-77.

4. Moniruzzaman S, Andersson R (2008) Economic Development as a Determinant of İnjurymortality- A Longitudinal approach. SocSci Med.

5. Smith GS (2003) Injury prevention: blurring the distinctions between home and work.Inj Prev 9: 3-5.

6. Devlet Planlama Teşkilatı, DPT (2003) İllerin ve Bölgelerin Sosyoekonomik Gelişmişlik Sıralaması Araştırması. Bölgesel Gelişme ve Yapısal Uyum Genel Müdürlüğü: 1-250.

7. Yıldız EB, Sivri U, Berber M (2010) Türkiye'de illerin sosyo-ekonomik gelişmişlik sıralaması (2010) Uluslararası Bölgesel Kalkınma Sempozyumu Bildiri Kitabı. Yozgat; Bozok Üniversitesi Yayınları 39: 147167.

8. Social Insurancelnstitution (SII) (2000) Statistical yearbook 2000. Ankara: Çalışma ve Sosyal Güvenlik Bakanlığı:115-167.

9. Social Security Institution (SSI). Statistical yearbook 2009.

10. Hämäläinen P, Saarela KL, Takala J (2009) Global trend according to estimated number of occupational accidents and fatal work-related diseases at region and country level. J Safe Res 40: 125-139.

11. Hämäläinen P, Takala J, Saarela KL (2005) Global estimates of occupational accidents. Saf Sci 44: 137-156.

12. Ceylan H (2011) Türkiye'deki İş Kazalarının Genel Görünümü Ve Gelişmiş Ülkelerle Kıyaslanması. International Journal of Engineering Research and Development 3: 18-24.

13. Takala J (1999) Global estimates of fataloccupationalaccidents. Epidemiology 10: 640-646. 